\title{
The Role of Translation activities as a Teaching Strategy in English Language Teaching for Rural Students
}

\author{
Bhargavi Pedda Ramireddy Gari \\ Research Scholar \\ Department of English \\ Sri Padmavathi Mahila Visvavidyalayam \\ Tirupati, Andhra Pradesh, India. \\ bhargaviprrg@gmail.com
}

\begin{abstract}
The human race on the globe lined with the letters and sounds of English. The English language has been proved as significant for a long time now. In this computerized era language is a nightmare to first-generation learners because it is costly in the market where they cannot afford to own. So, this paper is going to address the importance of the Translation and Translation Activities in language classrooms to teach first-generation learners and justify why the Translation method is suitable to rural background students to learn LSRW skills. It also explains how these learners are going to improve vocabulary, writing, and speaking styles, filling vocabulary gaps in L1 and L2, understanding concepts and word recall and retention.
\end{abstract}

Keywords- Second Language, Translation, Translation Activities, Rural students, LSRW Skills 


\section{Introduction}

India is a vast land of incredibility and diversity. The variety that our country offers in people, their costumes, language, religion, etc. occupies a unique place in the entire world. The only element that links the whole country in unison is the attitude of being Indian and; the link language, Hindi, and English. Though English is being taught as a second or foreign language in educational institutions, the importance of English in India can easily be understood as it is accorded the associate official language status. So far higher education and career growth is concerned, it can be said to be the only language which promises to give a leap in career. English is an international language, spoken in many countries as a native or as a second or foreign language. It is the language of communication among countries, the language of trade and commerce, science and technology, medicine and law, global news and views etc. Above all, it is the language of the library and higher education. So, a student in India cannot just do away with this language.

In this context, work must be carried out on students' language skills from the basic to the higher level. India is full of villages and the origins of Indian identity come known as these. The majority of the population lives in the villages. Educational growth in the last 73 years of independence is not as expected. Here the first-generation learners from the rural background who are not exposed to the English language from all sections are getting many hurdles in English language learning. The Translation activities method assists them to overcome hurdles in second language learning. The translation method improves student's English language skills which are compulsory for pursuing higher education and taking up the right career. In addition, students are able to learn four basic language skills with the help of their mother tongue, in the English language. So, the Translation method allows students to relate unknown language to known language which leads to an effective language learning process in the EFL classroom. 
Translation in Teaching Second Language

Translation has been neglected in second or foreign language (FL) classrooms because it was considered an inadequate reminder of old teaching methodologies, especially those associated with (or derived from) the Grammar Translation method. This became increasingly the birth of the Direct, Natural, and Communicative Language Teaching methodologies. which considered translation as detrimental for the learning of the new language. The translation seems to be still largely ignored and deiminated in FL teaching contexts. As though scholars and FL native teachers have argued that translation should be avoided in the language classroom since it is not a useful tool but recent studies show that translation can be a great aid to foreign language learning and the importance of the translation method had been highlighted by the same in the case of first-generation English language learners who are not exposed to the English language earlier.

\section{Translation in EFL Classroom}

The present paper emerged out of long-term teaching experience and it was observed that translation as a method applied to the area of language teaching provides greater insight into the substantive nature of the instructional materials. The topic addressed in the paper is translation's importance to improving foreign language skills among first-generation English language learners. The aim of this essay is to prove that translation is a legitimate approach for the practice and learning of new languages. The paper's aims are, first, to identify the translation practices that increase knowledge of language use between students and, second, to analyze the utility of translation in learning English. The study approaches are an overview of the theoretical context, a description of the language classroom translation procedures, and an analysis of the results of my classroom observation. 
Most scholars, linguists, and teachers believe in the value of using foreign language courses for translation. Consistent with Schaffner (1998), that the translation and related practices could be useful for understanding the foreign language:
i. To improve verbal agility.
ii. $\quad$ To expand students' vocabulary in L2.
iii. To develop their style.
iv. To improve their understanding of how languages work.
v. To consolidate L2 structures for active use.
vi. To monitor and improve the comprehension of $L 2$.

The translation is an adequate method in language learning and is viewed as how to enhance the talents of second language learners. Translation encourages students to find out reading, writing, vocabulary, grammar, and communication. Consistent with Researcher Ross (2000), Translation enhances communication and understanding which regarded as the fifth skill and also very essential to survive within the society. The translation may be a very useful gizmo within the teaching of foreign languages to extend cooperation, collaboration among students. Duff(1986) states that" the language competence may be a two-way system, yet little guidance is given the way to communicate back into the mother tongue".

Translation increases the comprehension capacity of second language learners. While translating students compare and develop linguistic knowledge of both languages. It is timesaving because students can understand quickly abstract nouns, mainly passive vocabulary than other methods, and also useful in giving instructions. The target language is often learnt by the support of the knowledge of the student's mother tongue. Translation activities may be used to develop the linguistic awareness difference between the mother tongue and the target language. The activities must be designed based on assimilated structures and grammatical 
patterns of both languages for linguistic transfer which leads to improvement of both language skills and we must create awareness on non-assimilated items in both languages

\section{Translation Activities in EFL Classroom}

The role of translation is not negligible since it produces a linguistic transfer of interference facilitating the teaching and learning process fruitfully. Consistent with Duff (1994) "Translation activities develop three qualities essential to all for the learning of language with accuracy, clarity, and flexibility". The translation may be a valid productive activity which will improve the training process. The utilization of L1 and code-switching help them in language acquisition. Xhemaili (2013) believes that the maternal language may be a powerful resource which will be utilized in several principled ways to reinforce learning. Researchers Nolasco and Artur (1995) state that translation activities create an opportunity to speak with others, encourage students to be innovative, thought-provoking, and that they use language for a purpose. Consistent with Ross (2000) "translation from L1 to L2 from L2 to L1 is recognized as the fifth skill and most vital social skill since it promotes communication and understanding among people”.

Translation activities are often supported for language learning especially for rural background students whose language exposure is very less. Consistent with Duff (1994) "properly designed translation activities are often employed to reinforce the four skills". The prime aim of the transaction activities is not to make them translators, but to assist the students in enhancing their English knowledge. Consistent with Cook (2010) "Translation helps create and maintain good relations between teacher and student, facilitates classroom management". The activities must be interesting and authentic which may be successfully applied at all levels and ages. They will be used as warm-up activities also. Translation activities are a valid tool when introduced meticulously planned and executed in an ESL/EFL 
classroom. Translation activities like Announcements, Conversations, Roleplay, News reading, Description of objector person or thing, compering enhance the public speaking skills of the students. Mbeudeu, c.d., (2017) attempted to explore the perception of Anglophone and Francophone teachers of EFL on how the introduction of translation-based activities in their classroom practices in Cameroon through interview and found that the translation strategies must be adopted for many reasons. That could foster students 'accuracy in writing and that an overwhelming majority of interviewees show a strongly positive attitude towards the introduction of task-based activities in teaching EFL in Cameroon.

The activities are classified into three categories. They are individual, pair, and group work depending on the nature of the activity. The teacher emphasized on one specific language skill while planning an activity. The translation activities teaching procedure is divided into three stages namely preparation, presentation, and practice. In the initial stage, which is the preparation stage, the teacher motivates the students and briefs them about the activity, and also gives them a set of instructions that they have to follow during the activity. Most of the activities are done first in their mother tongue (L1) which guides them while doing the activities in their target language (L2) but some activities are done in both languages simultaneously. In the second stage, the presentation stage the teacher executes the activities one after another in the class and while executing them the teacher facilitates and assists the students wherever they feel difficulty in their learning process and guides them properly to complete the activity in a smooth and successful manner. The ultimate stage is the practice stage. In this stage, teacher can provide worksheets which support the activities done by them previously which enhance their writing skill and reinforce their learning. 


\section{Conclusion}

The students may have difficulty in doing translation activities at starting, but by practice, they found translation is a useful learning resource. The translation Activities method is fun-filled and interesting to learn English as a second language. Students' confidence and comfort while learning a second language are amazing and not boring. They gradually turned into English as their own language and easily understood things compared to their native language. And moreover, this method is a huge benefit to the first-generation rural English language learners because of their background and circumstances. They can improve their vocabulary, writing, and speaking skills and while reading a text they can easily understand and can enhance their comprehension ability to understand new words. While doing translation activities students feel healthy competition to complete the task within the stipulated time which leads to better performance in both languages. The students, therefore, started to address common mistakes and correct them, improving themselves through recall and retention of the target words. The Translation activities method is taskbased and stress-free learning and preferred language teaching technique in the EFL classroom. 


\section{References}

Bibaiana Clavijo. "Identifying Translation in Teaching Strategies: An Exploratory Study." International Journal of Humanities and Social Science[Online],3.21 (2013):8 Web. Accessed on 13 Sep.2020

Brown, H. D. Principles of Language Learning and Teaching. 4th ed, New York, Longman, 2002.

Cook, Guy. Translation in Language Teaching: An Argument for Reassessment. Oxford, Oxford University Press, 2010.

Duff, A. Translation: Resource Books for Teachers. Oxford: Oxford University Press, 1994.

Duff, Alan. Translation. Oxford, Oxford University Press, 1989.

Inga Dagilienè. “Translation as a Learning Method in English Language Teaching." Studies About Languages [online], 21(2012):6. Web. Accessed on 15 Sep. 2020

Mbeudeu, C.D. "Introducing Translation-based activities in teaching English as a foreign language: A step towards the improvement of learners' accurate use of words and expressions in writing.” Research in Pedagogy [Online],7.1(2017):14. Web. Accessed on 14 Sep. 2020

Ross, N. J. "Interference and Intervention: Using Translation in the EFL Classroom." Modern English Teacher [Online],9.3 (2000):7 Web. Accessed on 14 Sep.2020

Penny, Ur. A Course in Language Teaching: Practice and Theory. Cambridge: Cambridge University Press, 1996.

Schaffner, C. Qualification for professional Translators, Translation in Language Teaching Versus Teaching Translation. Manchester, St. Jerome Publishing, 1998.

Xhemaili, M. The advantages and disadvantages of mother tongue in teaching and learning English for specific purposes (ESP) classes. Anglisticum Journal (IJLLIS), [Online], 2.3(2013):5 Web. Accessed on 15 Sep.2020 